\title{
EVIDENCE OF MANTLE INHERITANCE ON THE ULTRA-DISTAL WESTERN IBERIAN MARGIN FROM TRANSFORMED TOTAL MAGNETIC ANOMALY
}

\author{
Luizemara Soares Alves Szameitat ${ }^{1}, 2$, Francisco José Fonseca Ferreira ${ }^{1}$, Gianreto Manatschal ${ }^{3}$ and \\ Monica da Costa Pereira Lavalle Heilbron²
}

\begin{abstract}
Inheritance on continental lithosphere is considered as an important aspect on passive margins, since they may control magmatic budget and strain evolution during rifting and lithospheric breakup. On the distal Western Iberian margin, the transition to a steady state oceanic crust was little sampled and less investigated, in comparison to the more proximal parts near to the continental edge. In this work, we use marine magnetic data to analyze some aspects of the transition between the zone of exhumed continental mantle (ZECM) and the unequivocal oceanic crust, using transformed magnetic data. We observe that the end of the ZECM presents some straight magnetic features, especially at the eastern limit of the $\mathrm{J}$ anomaly. These magnetic lineaments are consistent with Early Cretaceous flow lines of the Iberian Plate. Straight structures are not expected in a newly formed oceanic lithosphere. Instead, it seems to be controlled by mantle inheritance. These straight magnetic features may indicate basement inheritance controlling magmatic insertions at the beginning of the oceanic crust formation.
\end{abstract}

Keywords: Iberia, magnetometry, Ocean-Continent Transition, inherited structures, magma-poor margin.

RESUMO. Estruturas herdadas na litosfera continental são um aspecto importante em margens passivas, pois poderão condicionar a entrada de magma e a evolução da deformação durante o rifteamento e quebra litosférica. Na porção distal da Margem Ibérica Ocidental, a transição da crosta continental até a crosta oceânica bem estabelecida possui menos dados e é menos investigada em comparação com a porção junto do limite de crosta continental. Neste trabalho, usamos dados magnéticos marinhos para analisar alguns aspectos entre a zona de exumação mantélica e a crosta oceânica inequívoca, através de dados magnéticos transformados. Observa-se que 0 final da zona de exumação mantélica apresenta algumas feições retilíneas, especialmente no limite leste da anomalia J. Estes lineamentos magnéticos estão em conformidade com linhas de fluxo mesozoicas da Placa Ibérica. Feições retilíneas não são esperadas em uma litosfera oceânica neoformada. Ao contrário, estas aparentam ser um controle dado por estruturas pretéritas do manto. Portanto, estas feições magnéticas retilíneas sugerem uma herança do embasamento continental controlando as intrusões magmáticas no início da formação da crosta oceânica.

Palavras-chave: Ibéria, magnetometria, transição continente-oceano, estruturas herdadas, margem pobre em magma.

\footnotetext{
${ }^{1}$ Universidade Federal do Paraná, Programa de Pós-Graduação em Geologia (PPGEOL) and Laboratório de Pesquisa em Geofísica Aplicada (LPGA), R. Francisco Heráclito dos Santos, 100, Building VI, 81531-980, P.0. Box 19045, Curitiba, PR, Brazil - E-mails: luizemara@ufpr.br, francisco.ferreira@ufpr.br ${ }^{2}$ Universidade do Estado do Rio de Janeiro, Faculdade de Geologia, Programa TEKTOS, R. São Francisco Xavier, 524, Building A 4020, 20550-030, Rio de Janeiro, RJ, Brazil - E-mail: heilbron@uerj.br

${ }^{3}$ Université de Strasbourg, Institut de Physique du Globe de Strasbourg, CNRS-UMR 7516, EOST, 1 rue Blessig, F-67084 Strasbourg Cedex, France - E-mail: manat@unistra.fr
} 


\section{INTRODUCTION}

Magnetic data are widely used on regional studies for passive margin characterization. On Western Iberia, several studies from magnetic data contributed to understand the tectonic framework from either Paleozoic (Lefort \& Haworth, 1979; Galdeano et al., 1990) and Mesozoic structures (Srivastava et al., 2000; Sibuet et al., 2007; Bronner et al., 2011; Whitmarsh \& Manatschal, 2012; Stanton et al., 2016). The Iberian and conjugate Newfoundland margins are among the best studied magma-poor rifted margins where mantle exhumation has been proven in the Zone of Exhumed Continental Mantle, ZECM Whitmarsh et al. (2001), by drilling and geophysical data (Srivastava et al., 2000; Whitmarsh et al., 2001; Whitmarsh \& Manatschal, 2012). However, most of the petrological and geophysical datasets of Western Iberia are close to the edge of the continental crust (Fig. 1), leaving a wide and yet little sampled area in the distal part of the ZECM and its transition to the well-developed marine magnetic anomaly 34 . Magnetic data can, in such a case, contribute to the geological interpretation of these little explored domains. The regional cover and several published maps (Miles et al., 1996; Verhoef et al., 1996) provide therefore a unique data set to explore nature of crust and processes leading to lithospheric breakup along the Iberia-Newfoundland conjugate rifted margins.

On present-day interpretations of rifted margins, the existence of a heterogeneous, inherited lithosphere is considered as important, since it may control the magmatic budget and strain evolution during final rifting (Chenin et al., 2015; Manatschal et al., 2015; Chenin et al., 2018). Observations on rifted margins show that the whole oceanic lithosphere may accommodate significant strain (Ribeiro, 2002). Our study supports the occurrence of a heterogeneous, inherited subcontinental lithosphere controlling the magmatic evolution during final rifting and early seafloor spreading along the ultra-distal Iberian passive margin. We use magnetic features to understand and characterize the nature of the crust between the ZECM and first unequivocal oceanic crust.

\section{GEOLOGICAL CONTEXT}

Western Iberia magma-poor rifting had propagated from south to north, with the first rifting phase about $200 \mathrm{Ma}$ and the last one starting $135 \mathrm{Ma}$. The oldest marine magnetic anomaly is $142 \mathrm{Ma}$, referred as M16 in the southern margin (Kullberg et al., 2013). The progressive rifting evolution was recorded on sedimentary basins along the slope of the Iberian margin (Alves et al., 2003; Kullberg et al., 2013).

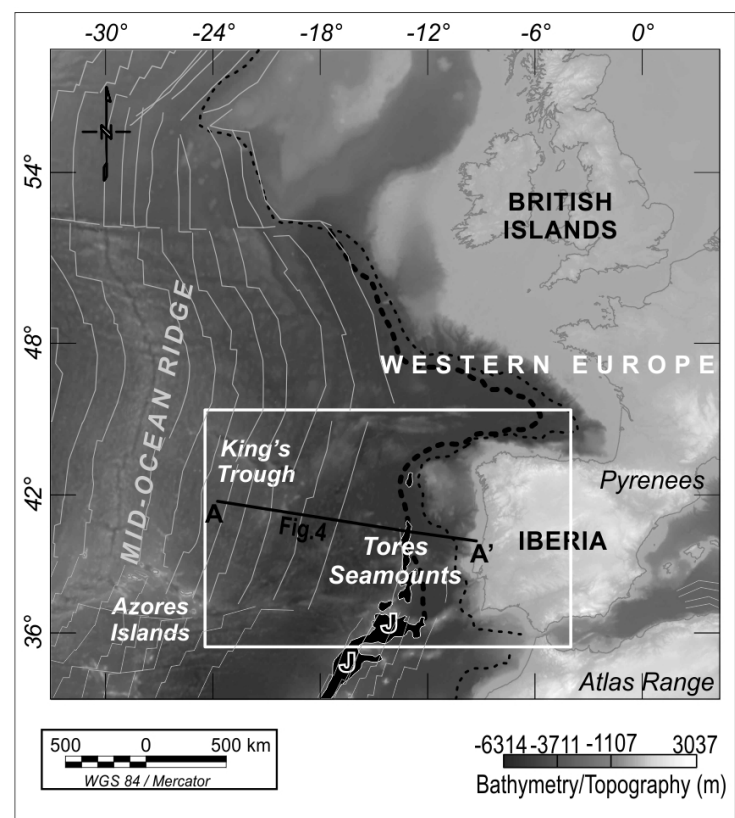

Figure 1 - Western Iberian Margin and location of the study area in Western Europe. Thin black dashed line: continental crustal domain based on Whitmarsh et al. (2001), Bronner et al. (2011), Alves (2012), Alves \& Heilbron (2013) and Nirrengarten et al. (2018). Thick dashed line: Zone of exhumed continental mantle (ZECM) adapted from Nirrengarten et al. (2018). Thin grey lines: magnetic isochrons, based on Müller et al. (1997). Black polygons (J): main positive part of $\mathrm{J}$ anomaly. Profile $\mathrm{A}-\mathrm{A}^{\prime}$ on Figure 4.

During the Mesozoic extension, approximately E-W transform faults accommodated this deformation (Kullberg et al., 2013; Nirrengarten et al., 2018), and it is possible that Paleozoic structures were reactivated (Stapel et al., 1996; Alves et al., 2003). However, the role of Variscan inherited structures during rifting remain uncertain (Kullberg et al., 2013; Dias et al., 2016).

Similar to present-day ridges, the opening axis of the ultra-distal Iberia-Newfoundland rifted margins may have been segmented during onset of seafloor spreading (Tucholke \& Ludwig, 1982; Srivastava et al., 2000; Nirrengarten et al., 2018), due to differentiated and structured Variscan lithospheric blocks (Stapel et al., 1996). In such a setting, transform boundaries are nearly perpendicular to the oceanic opening axis and subparallel to the drifting orientation.

Distinct margin-parallel rift domains are described oceanward, that are generated by successive stages of the margin evolution (Péron-Pinvidic et al., 2008; Whitmarsh \& Manatschal, 2012; Gillard et al., 2016; Naliboff et al., 2017). From continent to ocean, we have the end of the continental domain and the beginning of the ZECM (Fig. 1). Within this zone, the continental crust thinned to less than $10 \mathrm{~km}$ mainly by a complex interaction between low-angle detachment faults and ductile deformation 
leading to the complete embrittlement of the continental crust (Whitmarsh \& Manatschal, 2012; Gillard et al., 2016; Naliboff et al., 2017).

On magma-poor rifted margins, the division into margin domains have been severely related with the amount of sin-rift magmatic incursion. Syn-rift intrusive and extrusive mafic rocks are registered at the distal termination of the ZECM (Srivastava et al., 2000; Whitmarsh et al., 2001; Sibuet et al., 2007; Bronner et al., 2011; Minshull et al., 2014). In Western Iberia, the beginning of syn-rift magmatic additions roughly coincides with the $\mathrm{J}$ anomaly (Whitmarsh et al., 2001; Sibuet et al., 2007), a large positive magnetic feature (Fig. 1). Despite the orientation of the $J$ anomaly, it does not match with the ZECM limit orientation to the south (Nirrengarten et al., 2017), the abrupt change of the magnetic signal is an evidence of significant changes on lithotypes from the $\mathrm{J}$ anomaly to the west.

The $\mathrm{J}$ anomaly has been interpreted as a polygenic magmatic feature (Nirrengarten et al., 2017) that initiates around M0 time (Tucholke \& Ludwig, 1982; Srivastava et al., 2000), and could embraces M3 and M4 (Whitmarsh \& Miles, 1995). Unlike the 34 isochron, the M-series chrons are ill defined and not clearly identified on Western Iberia. They are well recognized southward of the Azores-Gibraltar Fault (Tucholke \& Ludwig, 1982). Ribeiro (2002) showed a regional basement structure that hosts the $\mathrm{J}$ anomaly (Tores-Madeira Seamounts) that indicates a regional lithospheric inheritance.

The magmatic incursion that overlaps with the location of the $\mathrm{J}$ anomaly has been interpreted as the continent ward termination of oceanic crust (Tucholke \& Ludwig, 1982; Chenin et al., 2015) or start of an embryonic oceanic crust (Fig. 1) that construct onto previously exhumed subcontinental mantle (Bronner et al., 2011; Stanton et al., 2016). From the J anomaly to the west, the basement might be formed by mafic additions (Whitmarsh \& Manatschal, 2012). At a lithospheric scale (Fig. 2), MORB-type melts percolated through the inherited subcontinental mantle and modified it into a refertilized mantle (Picazo et al., 2016).

As a result, we expect to have an embryonic type of oceanic crust between the poorly-magmatic exhumed mantle (e.g. ZECM) and the normal-magnetized oceanic crust from 34 isochron westwards. It may be composed by mantle rocks full of basic intrusions and covered by thin basaltic crust, as proposed on

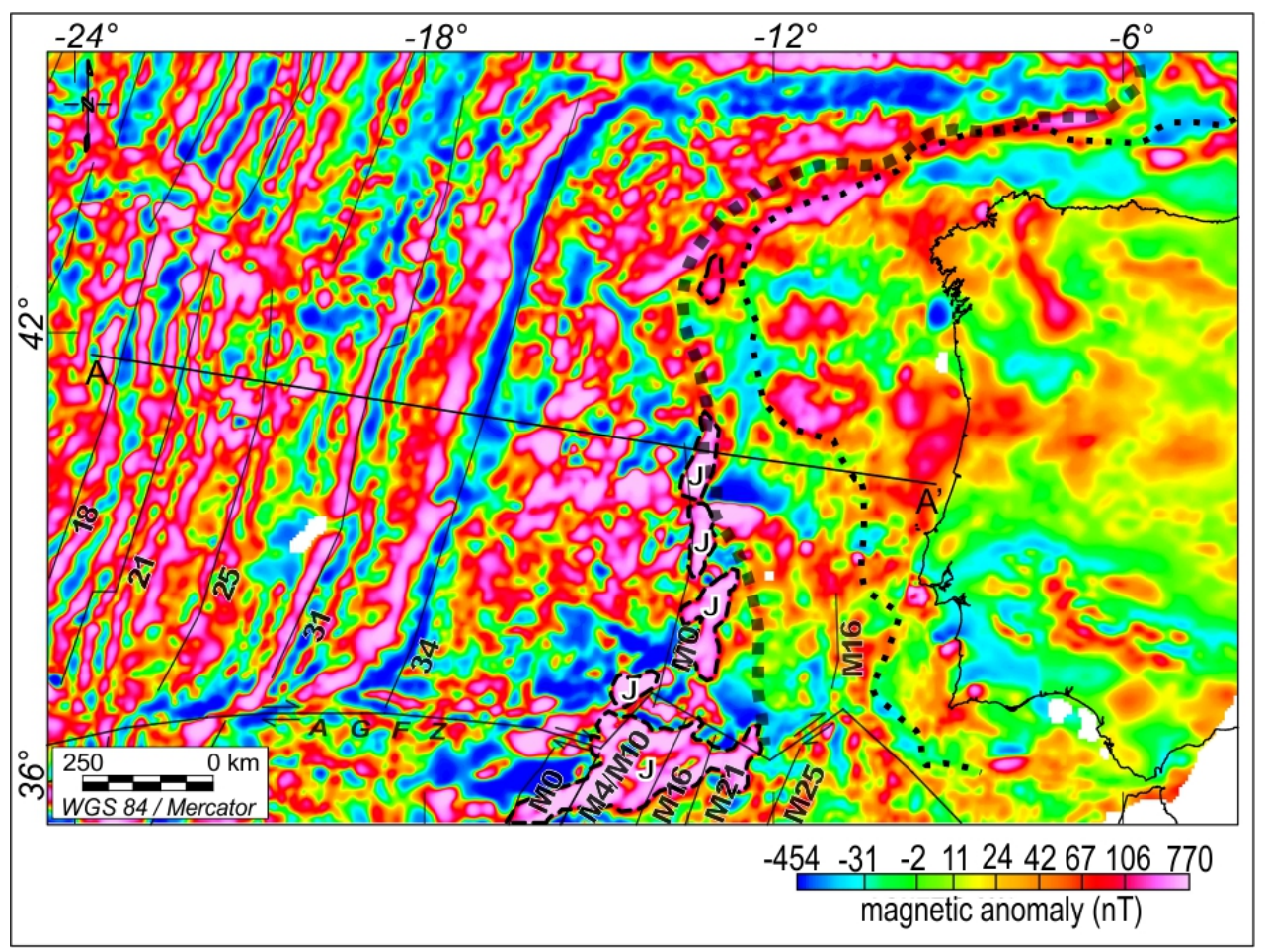

Figure 2 - Total Magnetic Anomaly (TMA) from Verhoef et al. (1996). J: positive part of J anomaly. Black thin dotted line: regional continental boundary. Black thick dotted line: the limit of the Zone of Exhumed Continental Mantle (ZECM). Magnetic isochrons are based on Müller et al. (1997). Profile A-A' on Figure 4. 
models for slow-spreading oceanic centers, e.g. crustal models in (Cannat et al., 2009; Bronner et al., 2014; Picazo et al., 2016).

\section{METHODOLOGY}

We use the Total Magnetic Anomaly (TMA) from Verhoef et al. (1996). This is a compilation of marine data acquisition and onshore grids, which has been used by several researches (Srivastava et al., 2000; Rovere et al., 2004; Sibuet et al., 2007). For the study area, this dataset is more accurate in comparison with more recent datasets, e.g. EMAG2 from Meyer et al. (2017). The final magnetic grid has $5 \mathrm{~km}$ of spatial resolution.

The Analytical Signal Amplitude (ASA) was applied as a method to localize magnetic source bodies (Nabighian, 1972). This filter is commonly used to examine source boundaries (Blakely, 1996), and works well on areas with high remnant magnetization and relatively shallow magnetic sources (Li, 2006). In general, the ASA filter produces high values above the source boundaries. However, it may shift the maximum values with increasing depth (Li, 2006). In addition, the result also depends on the source extension, dip and direction of magnetization in relation to the Earth magnetic field (Li, 2006). Despite of that, the result from ASA filter contributes to understand the magnetic anomalies without the additional ambiguity of inferred declination and inclination, as these parameters are rarely well-known in a regional area (Paine et al., 2001).

For this study, the vertical integral of ASA (VIAS) was applied in order to observe regional magnetic anomalies. Vertical integration can be used for magnetic interpretation without parameters of magnetization direction, and it reduces the response from shallow magnetic sources (Silva, 1996). VIAS anomalies are similar to the supposed original non-remnant anomalies and are located above their sources. However, their amplitudes are bit higher and the magnitudes tend to be lower than original non-remnant anomalies (Paine et al., 2001). Additionally, this filter gives values in $\mathrm{nT}$ instead $\mathrm{nT} / \mathrm{m}$, which is more suitable for interpreters (Paine et al., 2001).

\section{RESULTS}

The TMA map shows high variability of anomaly patterns along the Iberian margin. It shows a high-magnetized area westward of the ZECM bounded by the $\mathrm{J}$ anomaly area (Fig. 2). ASA (Fig. 3-A) and VIAS (Fig. 3-B) maps highlight the most magnetized areas. In a textural analysis, the ASA map shows many straight lineaments from abrupt interruptions of magnetic anomalies within the ultra-distal high-magnetized area (thin dashed lines between ZECM and 34 isochron on Fig. 3-C).

We consider that the most emphasized feature across the offshore passive margin on the ASA map is the eastern limit of the $\mathrm{J}$ anomaly area. It is a sharp feature that shows short and long fragments with WNW-ESE and NNE-SSW orientation (thick black and white line, Fig. 3-C).

The VIAS map points out the highest concentration of magnetic sources along the ultra-distal passive margin in a large anomalous area (Figs. 3-D and 4). This central anomalous area exhibits a more abrupt limit around the oceanward termination of the ZECM, and a relatively smoothed limit to the west. Along the Western Iberia margin, the strike of the eastern gradient of the high-magnetized area on VIAS approximately follow the ZECM limit as defined by Nirrengarten et al. (2018).

Straight features on ASA maps are smoothed and can be less clearly seen on the VIAS map. The main high amplitude area on VIAS becomes softer oceanwards (Fig. 3-D and profile A-A', Fig. 4), mostly after the beginning of recognized magnetic chrons. However, smoothed segmented features can be sighted into the further domain from 34 isochron to the west.

A regional profile is presented on Fig. 4 in order to illustrate the correlation between magnetic data and a possible geological model for this area. For this conceptual profile, the regional upper lithospheric setting and magmatic intrusions were based on Cannat et al. (2009), Bronner et al. (2011), Whitmarsh \& Manatschal (2012) and Picazo et al. (2016). We use a Moho Discontinuity from GEMMA dataset, computed from worldwide global gravity field (Reguzzoni \& Sampietro, 2015). The bathymetry is from ETOP01 (Amante \& Eakins, 2009).

\section{DISCUSSION}

Magnetic maps show that highest magnetization coincides with the oceanward limit of the ZECM. This supports the interpretation that the basement of the ZECM is regionally much lower magnetized, because of the lack of major large magmatic additions (Whitmarsh et al., 2001).

Westward from ZECM, it is noticed that the high-amplitude anomalous area on ASA and VIAS were developed during the Cretaceous Normal Superchron (CNS) on 34n chron. CNS corresponds to a 35 Myr long interval of normal magnetic polarity from Early Aptian to the Santonian/Campanian boundary (Gradstein et al., 2012). In fact, the anomalous ultra-distal area seems to follow the CNS, especially on the VIAS map. However, magnetic data observations advise that the VIAS large anomalous 
area shows more than just an isochron signature. It is important to note that the positioning of highest magnetic anomaly values is variable and does not depend on CNS positioning, which is located between M0 and 34. In other words, the basement is not homogeneously magnetized along the oceanic spreading axis, as we expect in a newly formed oceanic crust. Instead, the main magnetized area on ASA has a sinuous geometry and VIAS exhibits a significant change in values from north to south. Moreover, the western side of the VIAS anomaly crosses western isochrons. Therefore, we consider that the high amplitude anomalous area observed along the ultra-distal margin is not just a result of a homogeneous magnetic stripe. As an alternative, it may be interpreted as a signature of a polygenic basement full of embedded magmatic sources.

Flow lines of the Iberian Plate are referred on Figures 3-D and 5, adapted from a review on Nirrengarten et al. (2018). It can be seen that the WNW-ESE trending features are parallel to the flow lines referred to the continental breakup. Regarding segmented models for lithospheric breakup development (Srivastava et al., 2000; Nirrengarten et al., 2018), the WNW-ESE lineaments seem to correspond to a main stretching direction during the opening of the southern North Atlantic. Therefore, the sub-perpendicular NNE-SSW segments might be dominated by extension. As a result, the observation that the magnetic pattern appears segmented along flow lines suggest that there is a direct link between magma emplacement, kinematics and the location of the magnetic sources along the $\mathrm{J}$ anomaly. Straight structures as we observe at the $\mathrm{J}$ anomaly are not expected in a newly formed oceanic lithosphere. In fact, Ribeiro (2002) classified the lithosphere as "mature oceanic lithosphere" at the J anomaly area (at Tores Seamounts), contrasting with a "young oceanic lithosphere" at Azores, since its relative undisturbed oceanlike magnetic pattern.

The shape of this segmented structural pattern at the $\mathrm{J}$ anomaly area (black and white thick line on Fig. 3-C) is similar to some pre-Mesozoic faulting orientations structuring the Western Iberian margin (Kullberg et al., 2013) as well as the location of clusters of onshore and offshore earthquake epicenters that likely follow Variscan inherited trends (Custódio et al., 2015; Veludo et al., 2017). Despite of the precise structural meaning of these straight magnetic features, these observations suggest that an inherited subcontinental lithosphere may have played a role on the distribution/production of magmatic additions. This interpretation corroborates with a "non-oceanic" origin of the magnetic sources that are at the origin of the $\mathrm{J}$ anomaly and support the idea that this anomaly is not a classical oceanic magnetic anomaly, as proposed by Nirrengarten et al. (2017).

The $\mathrm{J}$ anomaly highlights the beginning of magmatic processes increasing oceanwards at the Western Iberian margin. However, a more precise limit of first oceanic crust (EOC, Fig. 4) was determined in the literature by the oceanward ZECM limit, which does not coincide with the location of the $J$ anomaly along the whole Iberian margin (Nirrengarten et al., 2018). This observation suggests that the sharp magnetic sources could be overlain by thin extrusive magmatic additions, which signature is not comprised in the ASA map. Magma emplacement within upper mantle and beneath oceanic crust is feasible and was described, for instance, on seismic profiles of the Western Somali Basin (Sauter et al., 2016).

The lack of magnetic signature from the beginning of the oceanic crust is feasible taking to account that the expectable geometry for the oceanic crust is an extended flat layer. In this case, it is possible that its geometry has no influence on magnetic features, since a uniformly magnetized flat layer cannot be detected on magnetic data alone (Blakely, 1996). Even if this basaltic layer geometry is similar to a wedge that progressively increases oceanwards, the smooth geometry of this layer might not give enough lateral property contrast, and this feature will be hardly detected. Furthermore, thrusted exhumed mantle on southern ZECM is covered by a $3 \mathrm{~km}$ thick basaltic layer (Gorringe Bank, Sallarès et al. (2013)). Therefore, the beginning of the basaltic crust in southern Iberia could be thinner than the magnetic dataset resolution, which also biases the interpretation of the oceanic crustal boundary. In any case, it is reasonable that the first basaltic layer can be magnetically undistinguishable, leading covered magnetic sources to be highlighted.

In a regional view, the major anomalous area on ASA and VIAS describe a regional sinuous trend (Fig. 3). This shape matches the Variscan orogenic trend in Western Europe, that can be represented by the Ibero-Armorican Arc (IAA) trend and the Late Variscan Porto-Tomar Fault Zone (PTFZ; e.g. Martínez-Catalán et al. (2007); IAA and PTFZ on Figs. 3 and 5). Also, it regards the horseshoe-shaped magnetic pattern on the conjugated Canadian margin detailed on Lefort \& Haworth (1979). High values on ASA and VIAS in the northern part describe a Variscan-like landward concavity that has been previously interpreted as continental inheritance (Alves, 2012; Alves \& Heilbron, 2013).

Segmented boundaries can be observed on VIAS central anomalous area, even toward to the UOC. From 34 to the west, 
(A)

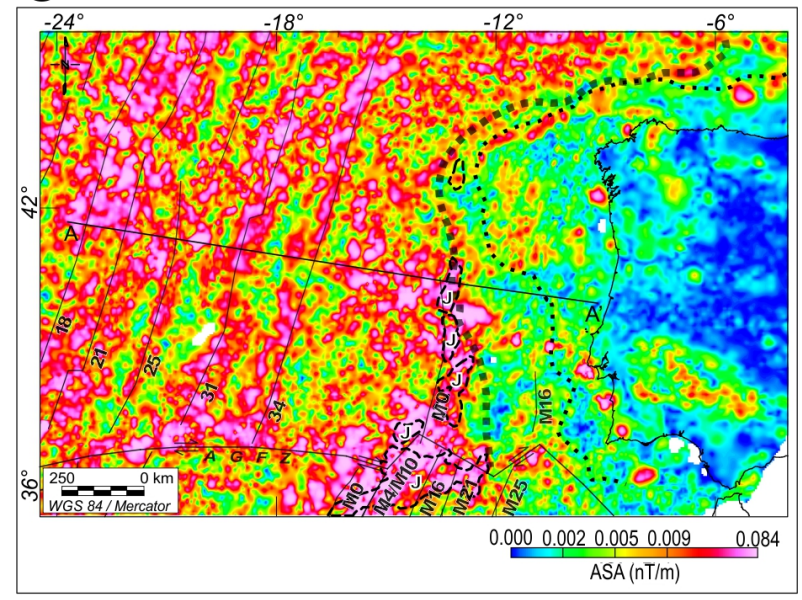

(C)

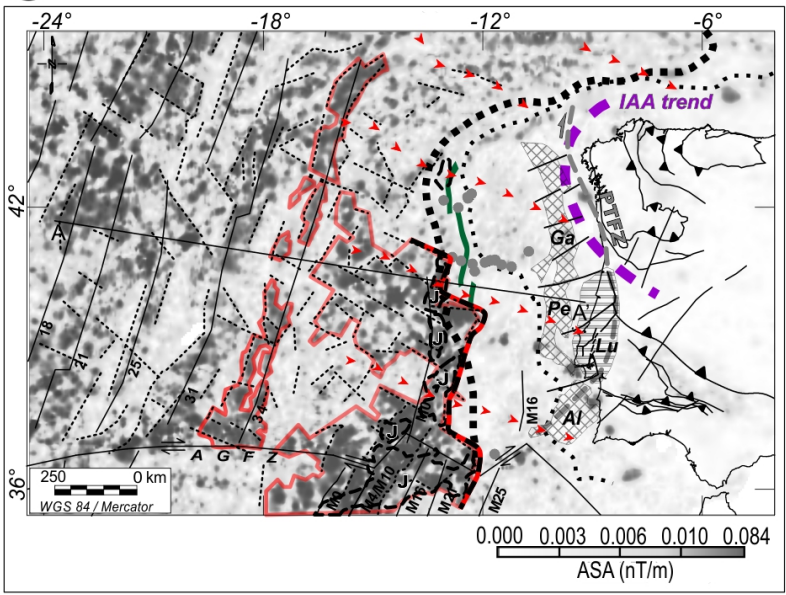

(B)

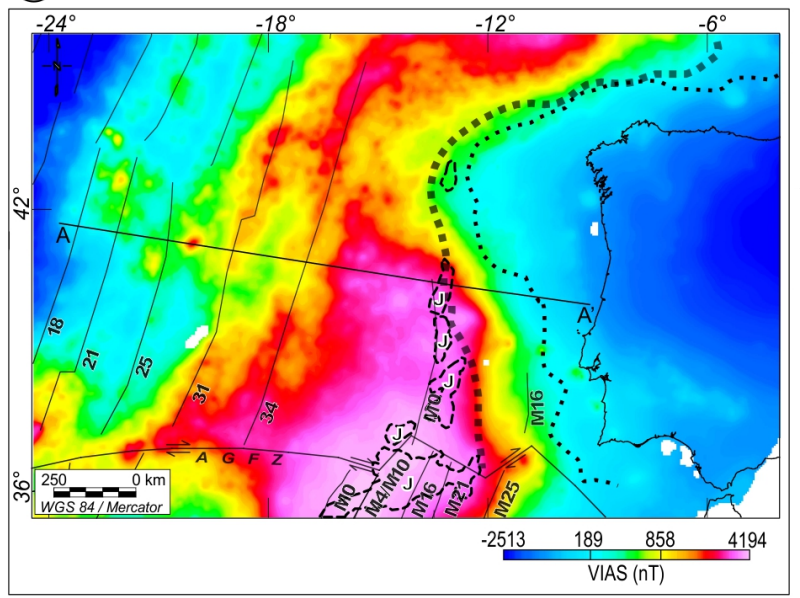

(D)

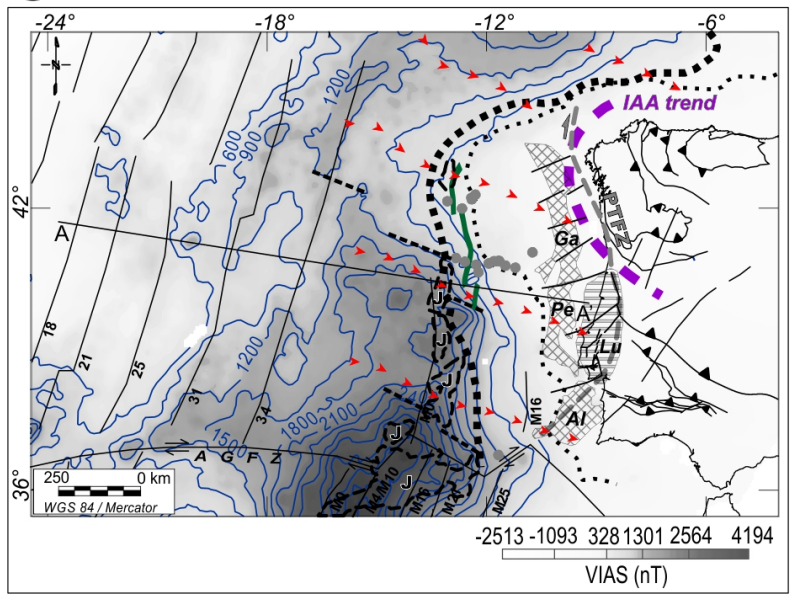

Figure 3 - Transformed magnetic data and interpretations. A: Analytical Signal Amplitude of TMA (ASA). B: Vertical Integral of ASA (VIAS). C: Summary of interpretations of ASA. The segmented limit of the $\mathrm{J}$ anomaly area is presented as a thick black-and-red dashed line. Ultra-distal anomalous area with a translucent red polyline. D: Interpretation of VIAS, with the detached main high-amplitude anomalous area. Red arrows: flow lines for Iberian Plate motion during Mesozoic adapted from Nirrengarten et al. (2018). Interpretations (lines): straight magnetic lineaments as black dashedlines based on 1) abrupt interruptions of magnetic anomalies; and 2) high gradient of anomalies. Thick black dashed outline: main positive part of $\mathrm{J}$ anomaly after Nirrengarten et al. (2018). Grey dots are Ocean Drilling Program (ODP) sites summaries. Dark green lines are alignments of peridotite ridges adapted from Whitmarsh et al. (2001). Black thin dotted line: regional continental boundary adapted from Whitmarsh et al. (2001), Alves (2012), Alves \& Heilbron (2013), and Nirrengarten et al. (2018). Black thick dotted line: the limit of the zone of exhumed mantle (ZECM) adapted from Nirrengarten et al. (2018). Magnetic isochrons are based on Müller et al. (1997). Sedimentary basins adapted from Kullberg et al. (2013): Ga, Galicia Basin; Lu, Lusitanian Basin; Pe, Peniche Basin; Al, Alentejo Basin. Ibero-Armorican Arc trend of the basement (thick dashed purple line), onshore main structures and Porto-Tomar Fault Zone during Late Variscan, based on Martínez-Catalán et al. (2007) and Dias et al. (2016). Profile A-A' on Figure 4.

it is certainly on a steady oceanic crust, since it has stable linear magnetic chrons. In this case, the significance of this segmented oceanward pattern on VIAS need further investigation. Nonetheless, it suggests that this inherent lithospheric structural network affects somehow a large crustal area, even on unequivocal oceanic crust domain. Therefore, this possible remaining network supports the westernmost extension of the subcontinental lithosphere under the beginning of the UOC (Fig. 4).

Regarding the rifted margin, a significant tectonic event was recorded at the transition between Late Aptian and Early Albian on distal margin (Péron-Pinvidic et al., 2007). Along Iberian margin, there is a regional discontinuity, with an abrupt input of siliciclastic material, Belasiano unit Kullberg et al. (2013), due 


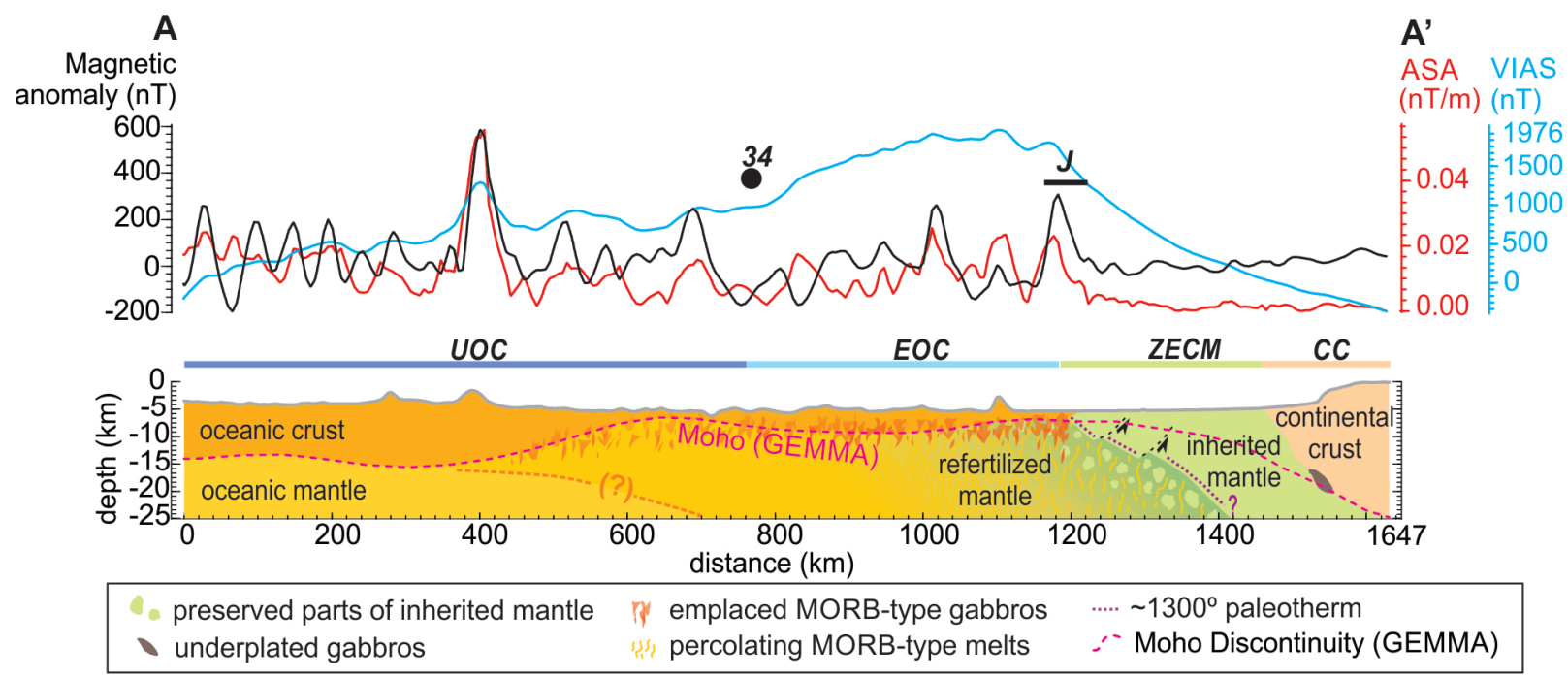

Figure 4 - Magnetic profile A-A' (location on Figs. 1, 2 and 3) and corresponding conceptual model. Schematic geological profile (see details on text). UOC: unquestionable oceanic crust. EOC: embryonic oceanic crust. ZECM: Zone of exhumed continental mantle. CC: continental crust. 34 and J: magnetic anomaly.
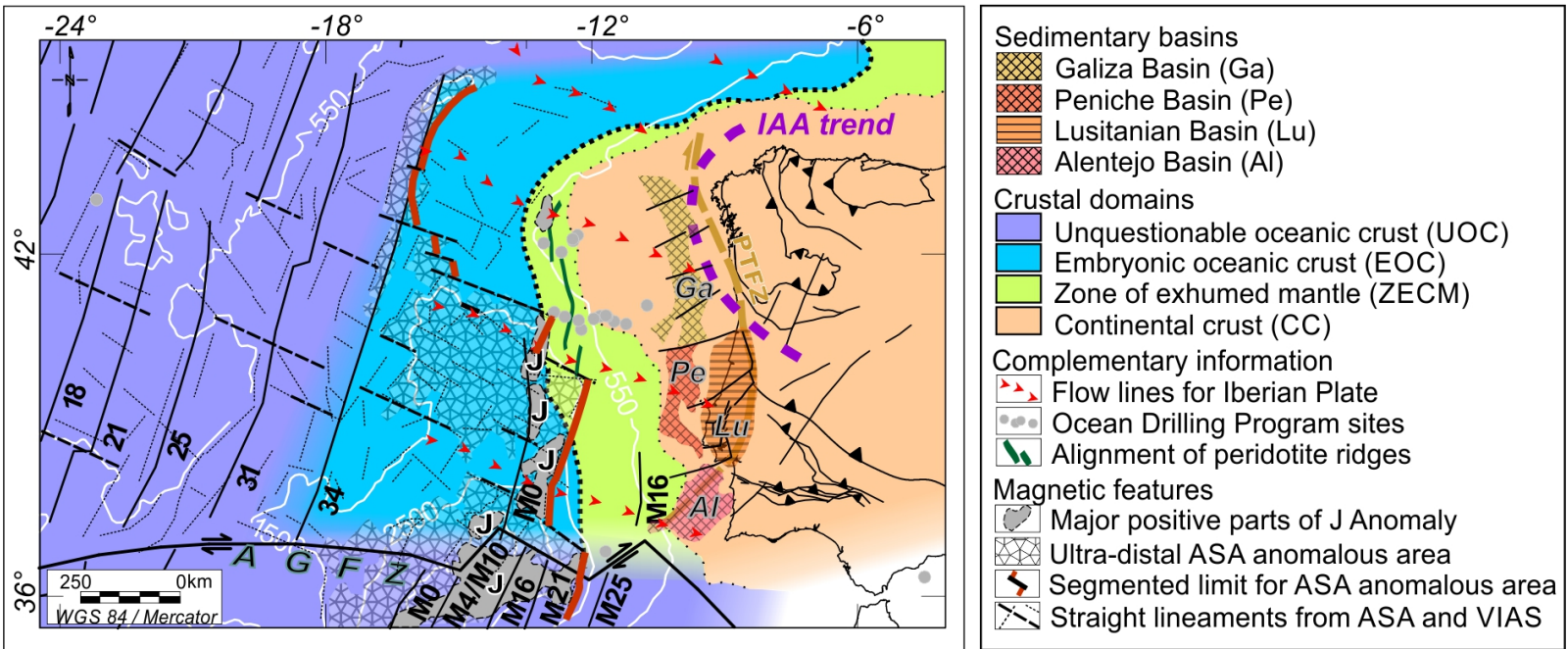

Figure 5 - Summary of interpretations. Examples of major and minor lineaments of ASA and VIAS maps, and interpretation for the segmented limit of the ASA anomalous area due to Mesozoic extension of an inherited lithosphere. Flow lines of Iberian Plate (red arrows) adapted from Nirrengarten et al. (2018). White contour lines: VIAS grid values. Sedimentary basins along W-Iberian margin: Ga, Galiza Basin; Lu, Lusitanian Basin; Pe, Peniche Basin; Al, Alentejo Basin. Detailed legend on Figure 3.

to the last rifting phase. This event is contemporaneous with a magmatic incursion along the $J$ anomaly, which has been linked with M0 isochron formation and lithospheric breakup, (Kullberg et al., 2013) and references therein.

Using VIAS map (Figs. 3-B and 3-C), we can compare regional magnetic features and the setting of slope basins along the Iberian margin. Along the ultra-distal anomalous area, the magnetic intensity increases to the south, and it is clearly anomalous southward from the Tores Seamounts area. This effect is illustrated by contour curves of VIAS values for this grid (Figs. 3 and 5). We can observe that the distribution of VIAS and ASA values roughly follow the partitioned pattern of Iberian slope basins (Kullberg et al., 2013), increasing by steps toward the south. In addition, it is estimated that the continental crust from Peniche Basin to the south has lower thickness than the northern margin, and this difference is likely to remain since 
Variscan Orogeny (Stapel et al., 1996). The role of Variscan inheritance through the sedimentary evolution of Iberian slope basins is observed (Alves et al., 2003), but a regional linkage between ultra-distal mantle interpretation and Iberian slope must be investigated further.

\section{CONCLUSIONS}

Transformed magnetic data provides information about the rifting evolution and magmatic incursion in Western Iberian margin. Ultra-distal magnetic features in Western Iberia led us to interpret a magmatic addition guided by a brittle structural network, which indicates an inherited and not yet completely oceanic lithosphere.

Both segmented eastern limit of ultra-distal magnetic domain and the south ward increasing of magnetic sources agree with the rifting process toward the north and the partition by E-W trending transform faults. For analytic signal amplitude and its vertical integration, the large interval of magma addition produced before 34 in the southwestern Iberian margin matches the highest magnetized area. Likewise, the lowest magnetic content is located next to the last rifted margin, in the northern part of margin.

\section{ACKNOWLEDGMENTS}

This research was supported by CAPES, Programa de Pós-Graduação em Geologia of Universidade Federal do Paraná (UFPR), Laboratory for Research in Applied Geophysics (LPGA-UFPR) and GeoAtlantico Institute - TEKTOS of Universidade do Estado do Rio de Janeiro (UERJ). The authors would like to thank M. Nirrengarten that improved the discussion of the magnetic maps. F.J.F. Ferreira was supported in this research by Conselho Nacional de Desenvolvimento Científico e Tecnológico (CNPq), under contract 306978/2015-6. The authors would also like to thank PETROBRAS, Faperj, and CNPq for their continued support.

\section{REFERENCES}

ALVES L. 2012. Estudo da margem continental ibérica ocidental com base em dados gravimétricos e magnetométricos regionais. Ph.D. thesis. Centro de Tecnologia e Ciências, Faculdade de Geologia, Universidade do Estado do Rio de Janeiro, Brazil. 133 pp.

ALVES LS \& HEILBRON MDCL. 2013. New concepts of continental passive margins: gravity and magnetic interpretation in West Iberia. In: 13th International Congress of the Brazilian Geophysical Society \& EXPOGEF, Rio de Janeiro, Brazil, 26-29 August 2013. Society of Exploration Geophysicists and Brazilian Geophysical Society. p. 344-349.
ALVES T, MOITA C, PINHEIRO L \& MONTEIRO J. 2003. Evolution of deep-margin extensional basins: the continental slope basins offshore West Iberia. In: AAPG International Conference, Barcelona, Spain, September 2003.

AMANTE C \& EAKINS BW. 2009. ETOP01 1 arc-minute global relief model: procedures, data sources and analysis. URL https://www.ngdc. noaa.gov/mgg/global/global.html.

BLAKELY RJ. 1996. Potential theory in gravity and magnetic applications. Cambridge University Press, Cambridge, 441 pp.

BRONNER A, SAUTER D, MANATSCHAL G, PÉRON-PINVIDIC G \& MUNSCHY M. 2011. Magmatic breakup as an explanation for magnetic anomalies at magma-poor rifted margins. Nature Geoscience, 4(8): 549.

BRONNER A, SAUTER D, MUNSCHY M, CARLUT J, SEARLE R, CANNAT M \& MANATSCHAL G. 2014. Magnetic signature of large exhumed mantle domains of the Southwest Indian Ridge-results from a deep-tow geophysical survey over 0 to 11 Ma old seafloor. Solid Earth, 5(1): 339-354.

CANNAT M, MANATSCHAL G, SAUTER D \& PERON-PINVIDIC G. 2009. Assessing the conditions of continental breakup at magma-poor rifted margins: What can we learn from slow spreading mid-ocean ridges? Comptes Rendus Geoscience, 341(5): 406-427.

CHENIN P, MANATSCHAL G, LAVIER LL \& ERRATT D. 2015. Assessing the impact of orogenic inheritance on the architecture, timing and magmatic budget of the North Atlantic rift system: a mapping approach. Journal of the Geological Society, 172: 711-720.

CHENIN P, PICAZO S, JAMMES S, MANATSCHAL G, MÜNTENER 0 \& KARNER G. 2018. Potential role of lithospheric mantle composition in the Wilson cycle: a North Atlantic perspective. Geological Society, London, Special Publications, 470: SP470.10.

CUSTÓDIO S, DIAS NA, CARRILHO F, GÓNGORA E, RIO I, MARREIROS C, MORAIS I, ALVES P \& MATIAS L. 2015. Earthquakes in Western Iberia: improving the understanding of lithospheric deformation in a slowly deforming region. Geophysical Journal International, 203(1): 127-145.

DIAS R, RIBEIRO A, ROMÃO J, COKE C \& MOREIRA N. 2016. A review of the arcuate structures in the Iberian Variscides; constraints and genetic models. Tectonophysics, 681: 170-194.

GALDEANO A, MIRANDA JM, MATTE P, MOUGE P \& ROSSIGNOL JC. 1990. Aeromagnetic data: a tool for studying the Variscan arc of Western Europe and its correlations with transatlantic structures. Tectonophysics, 177(1-3): 293-305

GILLARD M, MANATSCHAL G \& AUTIN J. 2016. How can asymmetric detachment faults generate symmetric Ocean Continent Transitions? Terra Nova, 28(1): 27-34. 
GRADSTEIN F, OGG JG, SCHMITZ M \& OGG G. 2012. The Geologic Time Scale 2012 Elsevier.

KULLBERG JC, ROCHA RB, SOARES AF, REY J, TERRINHA P, AZERÊDO AC, CALLAPEZ P, DUARTE LV, KULLBERG MC, MARTINS L, MIRANDA R, ALVES C, MATA J, MADEIRA J, MATEUS 0, MOREIRA M \& NOGUEIRA CR. 2013. A Bacia Lusitaniana: estratigrafia, paleogeografia e tectónica. In: DIAS R, ARAÚJO A, TERRINHA P \& KULLBERG JC (Eds.). Geologia de Portugal, Vol. II, Lisboa: Escolar Editora. p. 195-347.

LEFORT JP \& HAWORTH RT. 1979. The age and origin of the deepest correlative structures recognized off Canada and Europe. In: Developments in Geotectonics, Volume 15, Elsevier, p. 139-150.

LI X. 2006. Understanding 3D analytic signal amplitude. Geophysics, 71(2): L13-L16.

MANATSCHAL G, LAVIER L \& CHENIN P. 2015. The role of inheritance in structuring hyperextended rift systems: Some considerations based on observations and numerical modeling. Gondwana Research, 27(1): 140-164.

MARTíNEZ-CATALÁN JR, ARENAS R, GARCÍA F, CUADRA P, GÓMEZ-BARREIRO J, ABATI J, CASTIÑEIRAS P, FERNÁNDEZ-SUÁREZ J, MARTíNEZ S \& ANDONAEGUI P. 2007. Space and time in the tectonic evolution of the northwestern Iberian Massif: Implications for the Variscan belt. Geological Society of America Memoir, 200(21): 403-423.

MEYER B, SALTUS R \& CHULLIAT A. 2017. EMAG2: Earth magnetic anomaly grid (2-arc-minute resolution) version 3. National Centers for Environmental Information, NOAA. Model, doi: 10:V5H70CVX.

MILES PR, VERHOEF J \& MACNAB R. 1996. Compilation of magnetic anomaly chart West Iberia. Proceedings of the Ocean Drilling Program, Scientific Results, 149: 659-663. doi: 10.2973/odp.proc.sr.149.242. 1996.

MINSHULL TA, DEAN SM \& WHITMARSH RB. 2014. The peridotite ridge province in the southern Iberia Abyssal Plain: Seismic constraints revisited. Journal of Geophysical Research: Solid Earth, 119(3): 1580-1598.

MÜLLER RD, ROEST WR, ROYER JY, GAHAGAN LM \& SCLATER JG. 1997. Digital isochrons of the world's ocean floor. Journal of Geophysical Research: Solid Earth, 102(B2): 3211-3214.

NABIGHIAN MN. 1972. The analytic signal of two-dimensional magnetic bodies with polygonal cross-section: its properties and use for automated anomaly interpretation. Geophysics, 37(3): 507-517.

NALIBOFF JB, BUITER SJ, PÉRON-PINVIDIC G, OSMUNDSEN PT \& TETREAULT J. 2017. Complex fault interaction controls continental rifting. Nature Communications, 8(1): 1179.
NIRRENGARTEN M, MANATSCHAL G, TUGEND J, KUSZNIR N \& SAUTER D. 2018. Kinematic evolution of the southern North Atlantic: Implications for the formation of hyperextended rift systems. Tectonics, 37(1): 89-118.

NIRRENGARTEN M, MANATSCHAL G, TUGEND J, KUSZNIR NJ \& SAUTER D. 2017. Nature and origin of the J-magnetic anomaly offshore Iberia-Newfoundland: implications for plate reconstructions. Terra Nova, 29(1): 20-28.

PAINE J, HAEDERLE M \& FLIS M. 2001. Using transformed TMI data to invert for remanently magnetised bodies. Exploration Geophysics, 32(3/4): 238-242.

PÉRON-PINVIDIC G, MANATSCHAL G, DEAN S \& MINSHULL T. 2008. Compressional structures on the West Iberia rifted margin: Controls on their distribution. Geological Society, London, Special Publications, 306(1): 169-183.

PÉRON-PINVIDIC G, MANATSCHAL G, MINSHULL TA \& SAWYER DS. 2007. Tectonosedimentary evolution of the deep Iberia-Newfoundland margins: Evidence for a complex breakup history. Tectonics, 26(TC2011): 1-19.

PICAZO S, MÜNTENER 0, MANATSCHAL G, BAUVILLE A, KARNER G \& JOHNSON C. 2016. Mapping the nature of mantle domains in Western and Central Europe based on clinopyroxene and spinel chemistry: Evidence for mantle modification during an extensional cycle. Lithos, 266: 233-263.

REGUZZONI M \& SAMPIETRO D. 2015. GEMMA: An Earth crustal model based on GOCE satellite data. International Journal of Applied Earth Observation and Geoinformation, 35: 31-43.

RIBEIRO A. 2002. Soft Plate and Impact Tectonics. Springer \& Business Media, $330 \mathrm{pp}$.

ROVERE M, RANERO C, SARTORI R, TORELLI L \& ZITELLINI N. 2004. Seismic images and magnetic signature of the Late Jurassic to Early Cretaceous Africa-Eurasia plate boundary off SW Iberia. Geophysical Journal International, 158(2): 554-568.

SALLARÈS V, MARTÍNEZ-LORIENTE S, PRADA M, GRÀCIA E, RANERO C, GUTSCHER MA, BARTOLOME R, GAILLER A, DAÑOBEITIA JJ \& ZITELLINI N. 2013. Seismic evidence of exhumed mantle rock basement at the Gorringe Bank and the adjacent Horseshoe and Tagus abyssal plains (SW Iberia). Earth and Planetary Science Letters, 365: 120-131.

SAUTER D, UNTERNEHR P, MANATSCHAL G, TUGEND J, CANNAT M, LE QUELLEC P \& HORN BW. 2016. Evidence for magma entrapment below oceanic crust from deep seismic reflections in the Western Somali Basin. Geology, 44(6): 407-410. doi: 10.1130/g37747.1. 
SIBUET JC, SRIVASTAVA S \& MANATSCHAL G. 2007. Exhumed mantle-forming transitional crust in the Newfoundland-Iberia rift and associated magnetic anomalies. Journal of Geophysical Research: Solid Earth, 112: B06105.

SILVA JB. 1996. 2-D magnetic interpretation using the vertical integral. Geophysics, 61(2): 387-393.

SRIVASTAVA S, SIBUET JC, CANDE S, ROEST W \& REID ID. 2000. Magnetic evidence for slow seafloor spreading during the formation of the Newfoundland and Iberian margins. Earth and Planetary Science Letters, 182(1): 61-76.

STANTON N, MANATSCHAL G, AUTIN J, SAUTER D, MAIA M \& VIANA A. 2016. Geophysical fingerprints of hyper-extended, exhumed and embryonic oceanic domains: the example from the Iberia-Newfoundland rifted margins. Marine Geophysical Research, 37(3): 185-205.

STAPEL G, CLOETINGH SE \& PRONK B. 1996. Quantitative subsidence analysis of the Mesozoic evolution of the Lusitanian basin (West Iberia margin). Tectonophysics, 266: 493-507.

TUCHOLKE BE \& LUDWIG WJ. 1982. Structure and origin of the J anomaly Ridge, western North Atlantic Ocean. Journal of Geophysical Research: Solid Earth, 87(B11): 9389-9407.
VELUDO I, DIAS NA, FONSECA PE, MATIAS L, CARRILHO F, HABERLAND C \& VILLASEÑOR A. 2017. Crustal seismic structure beneath Portugal and southern Galicia (Western Iberia) and the role of Variscan inheritance. Tectonophysics, 717: 645-664.

VERHOEF J, ROEST WR, MACNAB R, ARKANI-HAMED J \& Members of the Project Team. 1996. Magnetic anomalies of the Arctic and North Atlantic oceans and adjacent land areas. Geological Survey of Canada. Dartmouth, Nova Scotia. Open File 3125.

WHITMARSH RB \& MANATSCHAL G. 2012. Evolution of magma poor continental margins: from rifting to the onset of seafloor spreading. In: Regional Geology and Tectonics: Phanerozoic Passive Margins, Cratonic Basins and Global Tectonic Maps, Elsevier, p. 326-341.

WHITMARSH RB, MANATSCHAL G \& MINSHULL TA. 2001. Evolution of magma-poor continental margins from rifting to seafloor spreading. Nature, 413(6852): 150.

WHITMARSH RB \& MILES PR. 1995. Models of the development of the West Iberia rifted continental margin at $40^{\circ} 30^{\prime} \mathrm{N}$ deduced from surface and deep-tow magnetic anomalies. Journal of Geophysical Research: Solid Earth, 100(B3): 3789-3806. 